\title{
Consciousness, Divinity and Trinity of Human Form
}

\author{
Kanta Arora \\ Sanskrit Department, Dayalbagh Educational Institute (Deemed University), Dayalbagh, Agra, India
}

\begin{abstract}
Paper refers to the basic Indian philosophy of consciousness, trinity of its functions of creation, preservation and dissolution, trinity of modes of nature, trinity of belief in divinity as God the father, the son and the messenger and endeavors to explain the human form as trinity of microcosm of divinity with its awareness, strong urge and natural instincts operating as a tool, technician and transmitter of fulfillment of divine desire and functions.
\end{abstract}

Key words: Sattav-rhythm, Rajas-activity, Tamas-inertia, trinity-three modes of operation.

\section{Introduction}

Indian philosophy revolves around the belief that consciousness is that form, from which all things are born, and after being born they live, and into which they merge when they cease to be. It explains its trinity of function of creation, preservation and dissolution, trinity of modes of nature i.e. Sattva, Rajas and Tamas. Christianity describes the trinity of divinity as God the father, the son and the messenger.

\section{Materials}

I endeavor to explain the experience of microcosm of trinity of divinity as awareness, strong urge and natural inclination in human forms. The essence of human form is consciousness which works as a tool, technician and transmitter (the apparatus that transmits the wireless waves through the air or telegraphic apparatus which converts sound waves) of divinity or the Ultimate Reality for its desire for expansion, maintenance and dissolution process. I have my own reasons to believe that among all the uncertainties of life, there are certain physical and experiential realities, which every individual is aware of fully well. Yet there is always uncontrollable overshadow of strong natural urges and inclinations in

Corresponding author: Kanta Arora, Dr., M.A., Ph.D., research field: philosophy of life in the light of enlightened experiential and physical realities of life. our behavior in practical individual life one actually lives.

Everyone knows that our life is short lived and one is bound to leave this world and face death at the end of life's journey. None of the worldly relations can last longer to accompany us always in life or beyond life. We have to leave all relations behind us and go alone. We cannot carry anything with us. Yet some take birth, and act as sinners or men of virtue with a hope to live here comfortably as long as they can, forgetting the physically experienced reality. They believe in continuity of life through their progeny, feed their ancestors on occasions and dream of their well being both of living and dead relations. They wish to leave behind them their rich off spring with a hope to feed them when they leave this world. In spite of their sufferings and pain in life their jest to live a long life along with the kith and kin never dies. They intend to accumulate more and more for themselves and assure that they leave behind enough for their family. The knowledge of transitory nature of existence does not discourage them for their struggle to expand and accumulate their possessions. These people of vice or virtue, in fact, act as tools for enforcement of Divine Will for continuity and expansion of His creation.

Some incline to grapple with search in pursuit of making this world more comfortable by their perceived and experimented innovations in physics, 
medical and all other type of sciences. They work hard for it without minding for the transitory character of all creation. They dream of unveiling the mask of the Ultimate Reality. They act like Budhas in search of physical cosmic laws with cherished vision to create a robot of human form and exercise control over creation. Their ambitions are very high and struggle day and night in pursuit of innovations in life for a better look, comfortable living and name and fame in life and death. The knowledge of the fact that change is eternal and everything will lose its glitter with time does not dissuade them from their vision and efforts for its achievement. Whatever may be their aspirations, goal or vision, in fact they are the technicians of the Divine Will for maintenance and beautification of His Creation. These men live in the realms of duty, action \& knowledge and are held very high as experts, professionals and friends of life for mankind.

However the Divine Will seems in favor of a plan for redemptions of all humanity at large and sends reminders that human life is short lived and the free will to live \& expand the awareness to sustain the worldly comforts or knowledge is limited. The chosen few are blessed to live ever attuned to the Ultimate reality. These men live in unoccupied awareness in pure consciousness. Their consciousness is not occupied with any cognition, thought, or cognition related experiences, senses or their retrieval. They live with the illuminating principle of experience which is shared in common by all forms of knowledge by self (essence of man) in oneness with the ultimate reality. They live in human form, apparently like human beings, receive through Surat Sabad Yoga (Spontaneous concentration of mind) wireless waves through the sound current and convert sound waves like telegraphic apparatus, interpret and transmit the Divine Will to humanity at large for their welfare. We may find such rare blessed human forms in every age who become source of spiritual illumination. This is true for all incarnations, saints and seers prophets and preachers of truth known or unknown who rose above the glamour of worldly life. They live in the realm of ecstasy, power and abode of truth. Such saints often chant that they say and transmit only the word or message of God.

\section{Results}

Enlightened experiential realities of life lived make it believe that the trinity of awareness, strong urge and natural instincts in human form functions as a tool, technician \& transmitter of Cosmic Will for its expansion, preservation and dissolution activity. 